\title{
Redaksjonelt
}

\section{De første publiseringer i 2010: Muntlige ferdigheter i engelsk som fremmedspråk}

ADNO presenterer med dette de to første artiklene i årgangen 2010. At begge artiklene er engelskspråklige, signaliserer ingen endring i tidsskriftets språklige profil. Vi vil fortsatt være et tidsskrift for norskspråklige publikasjoner med utgangspunkt i norsk fagdidaktisk forskning. Vi har imidlertid helt fra starten åpnet for at forfattere innenfor feltet engelsk fagdidaktikk kan få benytte sitt naturlige arbeidsspråk i sine publikasjoner.

De to artiklene som nå publiseres, er tematisk beslektede, idet begge tar for seg aspekter ved utvikling av taleferdighet innenfor engelsk som fremmedspråk. Et interessant poeng er at den ene artikkelen er skrevet av en nestor innenfor fagfeltet, mens den andre er skrevet av en masterstudent. Dette speiler en bredde innenfor forskningsfellesskapet som tidsskriftet ønsker velkommen. At masterstudenter deltar med publikasjoner på dette nivået, hører riktignok til sjeldenhetene, men det er ikke desto mindre gledelig for fagfeltet når en slik forfatter passerer det nåløyet som en vitenskapelig fagvurderingsprosess representerer.

Aud Marit Simensen er som nevnt en nestor innenfor engelsk fagdidaktikk i Norge. I artikkelen "Fluency: an aim in teaching and a criterion in assessment" oppsummerer hun viktige aspekter ved taleflyt ("fluency") i engelskundervisningen. Med utgangspunkt i nyere forskning framhever Simensen betydningen av utfyllende småord og fraser for å gi den talende tid til å utforme nye setninger. Forfatteren konstaterer at taleflyt som fenomen har hatt et noe varierende fokus i norske læreplaner, men at fenomenet står sentralt i K06, og at dette gjenspeiler et internasjonalt fokus på taleflyt i fremmedspråksundervisning. I siste del av artikkelen peker Simensen på to viktige anliggender som framheves i litteratur om språklæring. Det ene er betydningen av å lære småord, fraser og lengre språklige segmenter, det andre er å oppøve en form for automatisering i bruken av slike språklige elementer.

James Coburn tar oss med til en spennende internasjonal læringsarena i sin artikkel "Teaching Oral English Online - Through Skype (VOIP)". Et ideelt fundert, akademisk institutt tilbyr nettbasert universitetsutdannelse til studenter i Iran som av livssynsmessige grunner ikke har adgang til de ordinære universitetene. Den nettbaserte virksomheten involverer akademisk personell fra Nord-Amerika, Latin-Amerika, Europa, Afrika og Asia. Coburn undersøker hvordan såkalte samtaletilretteleggere ("Conversation Facilitators") via Skype utvikler ferdigheter i muntlig engelsk hos iranske studenter. Han har intervjuet åtte slike tilretteleggere som leder individuelle samtaler eller gruppesamtaler med studenter på grunnleggende kurs. I sin studie framhever forfatteren hvordan kommunikasjonssituasjonen blir tilrettelagt for å gjøre det mer overkommelig 
for studentene å bruke et fremmed språk i samtale med en tilrettelegger de i utgangspunktet ikke kjenner. Differensiering av oppgaver framheves som et viktig grep i denne sammenheng. Et annet grep er å utvikle en sosial samarbeidskultur hvor både student og lærer kan gjøre bruk av større deler av sitt interessefelt.

Sett i sammenheng viser disse artiklene hvordan et språkdidaktisk fenomen som taleferdighet kan belyses fra ganske ulike synsvinkler. Gjennom sine respektive teoriforankringer illustrerer artiklene dessuten noe av det teoretiske spenningsfeltet som språkdidaktikken opererer innenfor. Simensen er i sin artikkel orientert mot en kognitivt fundert forskningstradisjon med vekt på hukommelsesfunksjoner, mens Coburn tar utgangspunkt i Vygotskys proksimale utviklingssone og dermed knytter seg til en mer sosiokulturelt orientert forskningstradisjon. Fagdidaktikken som fag- og forskningsfelt er i sin natur tverrdisiplinær. Nettopp derfor kan det være grunn til å la ulike forsknings- og teoritradisjoner møtes for å utfordre og berike hverandre.

De manuskriptene som tilflyter redaksjonen, spenner over et relativt betydelig spekter av sjangre. Ut fra de erfaringene vi så langt har gjort, ser vi behov for å tydeliggjøre noen normer for den vurderingen vi foretar i redaksjonen. Disse normene blir synliggjort i en egen redaksjonell artikkel. Vårt håp er at en klargjøring av slike normer vil skape mer entydige rammer for kommunikasjonen mellom forfattere, fagfellevurderere og redaksjon, og at normene dermed vil styrke konsistensen og forutsigbarheten i de redaksjonelle vurderingsprosessene.

Med disse ord åpnes 2010-årgangen av Acta Didactica Norge offisielt for våre lesere. Vi imøteser publisering av flere artikler som er i prosess, og ønsker selvsagt velkommen ytterligere innsendte bidrag til det fagdidaktiske forskningsfeltet.

Oslo, mai 2010

Jon Magne Vestøl

Ansvarlig redaktør 